\title{
Idiopathic full thickness macular hole in a 10-year-old girl
}

\author{
Li-Anne S. Lim ${ }^{1,2^{*}}$ (D, Guillermo Fernandez-Sanz ${ }^{1}$, Steven Levasseur ${ }^{1}$, John R. Grigg ${ }^{1,2}$ and Alex P. Hunyor ${ }^{1,2}$
}

\begin{abstract}
Background: Macular holes in children are generally associated with trauma.

Case presentation: We report the first case of an idiopathic full thickness macular hole in a 10-year-old girl. 23-gauge transconjunctival pars plana vitrectomy, induction of a posterior vitreous detachment, ILM blue-assisted internal limiting membrane peel, fluid-air exchange and air-26\% sulfur hexafluoride (SF6) exchange was performed with subsequent macular hole closure.
\end{abstract}

Conclusion: This is the first reported case of an idiopathic full thickness macular hole in a child. Treatment with pars plana vitrectomy with peeling of the ILM resulted in significant anatomic and functional improvement.

Keywords: Macular hole, Children

\section{Background}

A macular hole is a full thickness defect in the neural retina at the fovea. It is thought to occur as a result of pathological changes at the foveal vitreoretinal interface [1]. Idiopathic macular holes most commonly occur in adults in the 6th to 7th decade [2]. Macular holes in children are rare and are generally associated with trauma [3]. We present a case of an idiopathic full thickness macular hole (FTMH) in a child.

\section{Case presentation}

A 10-year-old girl presented with reduced vision in the right eye. The vision had deteriorated from 20/17 1 year previously, to $20 / 60$. She was otherwise well, with no history of trauma or inflammation of either eye and no other significant medical or drug history. Her grandfather, and grandfather's brother had a history of retinal detachment.

Visual acuity (VA) was $20 / 60$ in the right eye and $20 / 20$ in the left eye. Ocular examination was unremarkable except for the presence of a FTMH in the right eye (Fig. 1). There was no evidence of trauma, inflammation or signs of retinal dystrophy. Optical coherence

\footnotetext{
*Correspondence: limlianne@gmail.com

${ }^{1}$ Sydney Hospital and Sydney Eye Hospital, Macquarie Street, Sydney, NSW, Australia

Full list of author information is available at the end of the article
}

tomography (OCT) showed a $365 \mu \mathrm{m}$ FTMH with no vitreomacular traction or posterior vitreous detachment (Fig. 2).

Following informed consent of her parents, we carried out a 23-gauge transconjunctival pars plana vitrectomy. Induction of a posterior vitreous detachment (PVD) was completed using triamcinolone, followed by ILM blueassisted internal limiting membrane (ILM) peel, fluid-air exchange and air-26\% sulfur hexafluoride (SF6) exchange. She was positioned face down for 3 days postoperatively. At postoperative week 1, VA was 20/60 with OCT evidence of hole closure (Fig. 3). At postoperative month 1, VA was $20 / 20$, and at 4 months postoperative, the macular hole remained closed with remodeling of the outer retina on OCT (Fig. 4). There was still a small defect at the photoreceptor level.

\section{Discussion}

There is only one previous report in the current literature of an idiopathic FTMH in a child. This case however, had features of cavitary maculopathy and did not have a full thickness defect [4].

In our case, the patient and her family were very reliable historians, strongly denying any possibility of antecedent trauma. Excellent vision of 20/17 was documented just 1 year prior by her optometrist. However, despite this, we must acknowledge, that given the active 


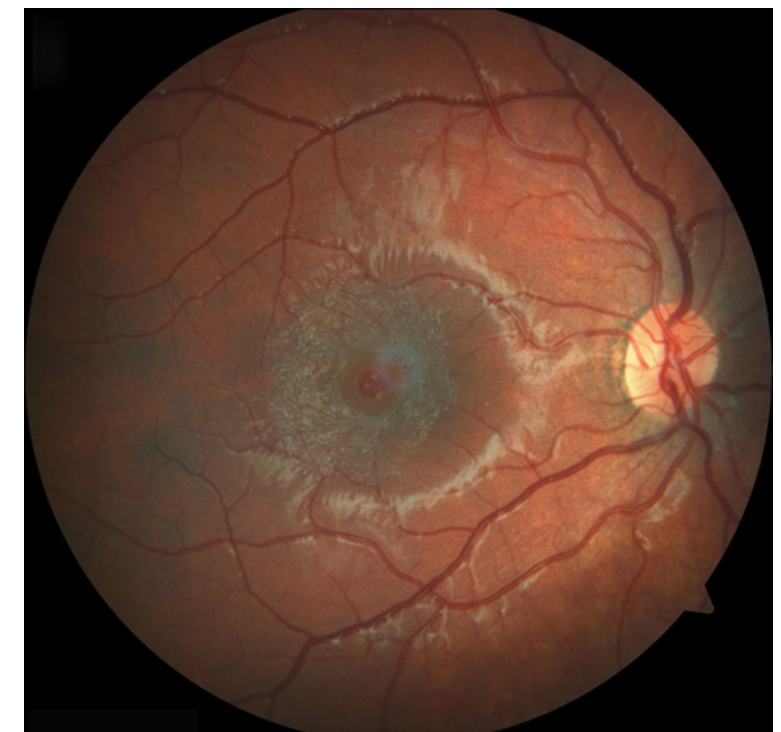

Fig. 1 Colour fundus photograph of the right eye shows a full thickness macular hole

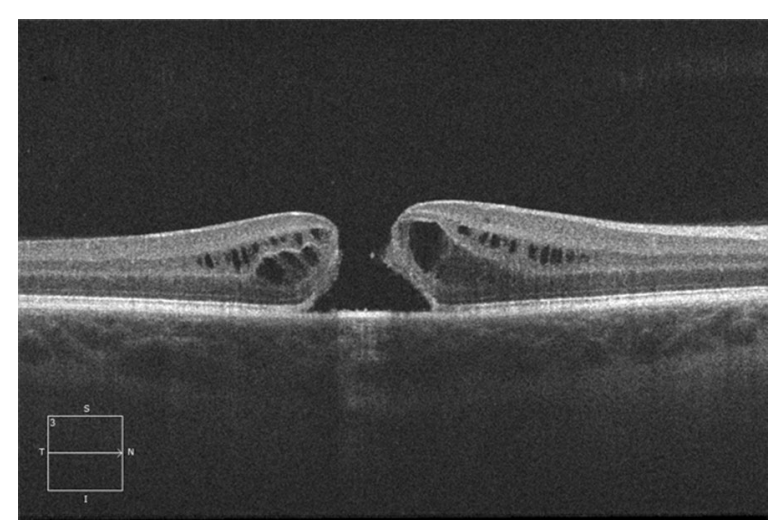

Fig. 2 Horizontal high definition spectral domain OCT of the right eye shows a full thickness macular hole

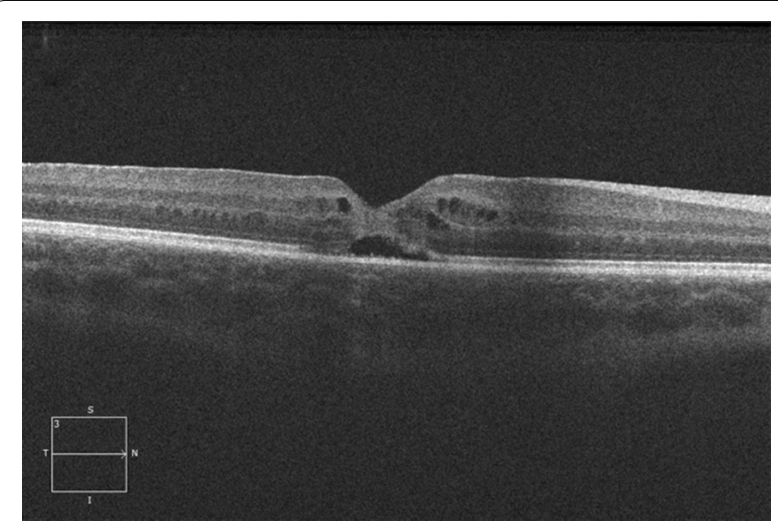

Fig. 3 Horizontal high definition spectral domain OCT of the right eye 1 week post operatively shows closure of the macular hole

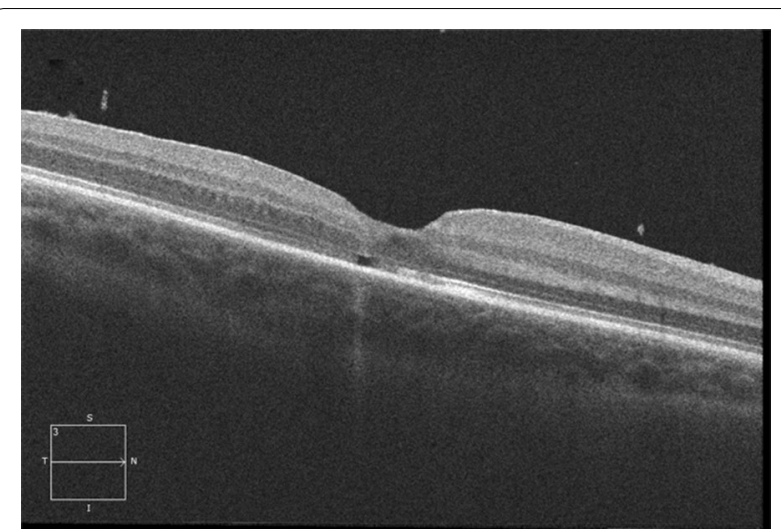

Fig. 4 Horizontal high definition spectral domain OCT of the right eye 1 month post operatively shows further improvement in macular architecture

nature of children it is possible that an unreported trauma may have occurred in our case. Children often do not immediately report their recent behaviors or visual symptoms, possibly out of fear of retribution or simply a lack of understanding. In addition, the possibility of non-accidental injury should always be considered as other life-threatening injuries and or situations may also be present.

In the setting of blunt trauma, the most common cause of macular hole in children, a contrecoup mechanism as a result of axial globe compression is thought to increase vitreomacular traction forces [5]. Our case illustrates an idiopathic FTMH in a child, in which neither vitreomacular separation or vitreofoveal traction could be visualized clinically or on OCT. The mechanism of idiopathic FTMH formation in a child remains unclear.

Review of the English language literature identified 15 pediatric eyes with a non-traumatic macular hole (Table 1). In contrast to our case, all had clinical or historical features of a secondary non-traumatic cause including: vascular (retinopathy of prematurity (ROP) [6], and Coats' disease [7, 8]), infective (Bartonella neuroretinitis [9-11]), and congenital (choroidal coloboma [12], regressed Bergmeister papilla [13]), and juvenile idiopathic epiretinal membrane [14]) entities. A case of accidental Nd:YAG laser induced macular hole in a child has also been reported, photothermal and photomechanical disruption of the retina occurring as a result of energy absorbed by the retinal pigment epithelium (RPE) [15]. The patients with ROP all had vitreoretinal surgery prior to discovery of the macular hole, and all had an associated retinal detachment. They were treated with a combination of open and closed vitrectomy in addition to a radial scleral buckle [6]. Of the 15 eyes, surgical hole 
Table 1 Summary of reported non-traumatic full-thickness macular hole in paediatric patients

\begin{tabular}{|c|c|c|c|c|c|c|c|c|c|}
\hline $\begin{array}{l}\text { Author, case } \\
\text { year }\end{array}$ & $\begin{array}{l}\text { Associated } \\
\text { cause } \\
\text { of macular } \\
\text { hole }\end{array}$ & $\begin{array}{l}\text { No. } \\
\text { of patients }\end{array}$ & Pt no. & $\begin{array}{l}\text { Patient age } \\
\text { (months, } \\
\text { yrs), gender }\end{array}$ & $\begin{array}{l}\text { Presenting } \\
\text { BCVA }\end{array}$ & $\begin{array}{l}\text { Size of hole } \\
(\mu \mathrm{m})\end{array}$ & Surgery & Outcome & $\begin{array}{l}\text { Last exam } \\
\text { BCVA }\end{array}$ \\
\hline \multirow[t]{5}{*}{ Ahmad 2005} & $\begin{array}{l}\text { Retinopathy of } \\
\text { Prematurity }\end{array}$ & 5 & 1 & $\begin{array}{l}10 \text { months } \\
\mathrm{F}\end{array}$ & Not reported & Not reported & $\begin{array}{l}\text { Yes } \\
\text { Scleral buckle } \\
\text { PPV+FAX }\end{array}$ & $\begin{array}{l}\text { Large macu- } \\
\text { lar hole }\end{array}$ & $20 / 3270$ \\
\hline & & & 2 & $\begin{array}{l}3 \text { years } \\
2 \text { months } \\
F\end{array}$ & Not reported & Not reported & $\begin{array}{l}\text { Yes } \\
\text { PPV+ ILM } \\
\text { peel +FAX } \\
\text { Cyanoacr- } \\
\text { ylate glue } \\
\text { applied to } \\
\text { the hole } \\
\text { Radial scleral } \\
\text { buckle }\end{array}$ & $\begin{array}{l}\text { Cyanoacr- } \\
\text { ylate glue } \\
\text { present } \\
\text { Retina } \\
\text { attached }\end{array}$ & $20 / 760$ \\
\hline & & & 3 & $\begin{array}{l}1 \text { year } \\
3 \text { months } \\
\text { F }\end{array}$ & Not reported & Not reported & $\begin{array}{l}\text { Yes } \\
\text { Radial } \\
\text { sponge } \times 2\end{array}$ & $\begin{array}{l}\text { Retina } \\
\text { attached }\end{array}$ & CF 2 feet \\
\hline & & & 4 & $\begin{array}{l}1 \text { year } \\
2 \text { months } \\
F\end{array}$ & Not reported & Not reported & No & $\begin{array}{l}\text { Total retinal } \\
\text { detach- } \\
\text { ment }\end{array}$ & NLP \\
\hline & & & 5 & $\begin{array}{l}2 \text { years } \\
M\end{array}$ & Not reported & Not reported & $\begin{array}{l}\text { Yes } \\
\text { Radial sponge } \\
\text { PPV + ILM } \\
\text { peel + sili- } \\
\text { cone oil }\end{array}$ & $\begin{array}{l}\text { Retina } \\
\text { attached }\end{array}$ & $20 / 360$ \\
\hline Albini 2005 & $\begin{array}{l}\text { Bartonella } \\
\text { Neuroreti- } \\
\text { nitis }\end{array}$ & 1 & 1 & $\begin{array}{l}10 \text { years } \\
\mathrm{F}\end{array}$ & CF 1 foot & $750 \times 500 \mu \mathrm{m}$ & No & Not reported & Not reported \\
\hline $\begin{array}{l}\text { Yokoyama } \\
2005\end{array}$ & $\begin{array}{l}\text { Juvenile } \\
\text { Idiopathic } \\
\text { Epiretinal } \\
\text { Membrane }\end{array}$ & 1 & 1 & $\begin{array}{l}3 \text { years } \\
\mathrm{F}\end{array}$ & $20 / 125$ & Not reported & $\begin{array}{l}\text { Yes } \\
\text { PPV + ILM } \\
\quad \text { Peel }\end{array}$ & $\begin{array}{l}\text { Macular hole } \\
\text { closed }\end{array}$ & $20 / 80$ \\
\hline Nakano 2005 & $\begin{array}{l}\text { Incomplete } \\
\text { regres- } \\
\text { sion of a } \\
\text { Bergmeister } \\
\text { Papilla }\end{array}$ & 1 & 1 & $\begin{array}{l}10 \text { years } \\
\mathrm{F}\end{array}$ & $20 / 25$ & Not reported & $\begin{array}{l}\text { Yes } \\
\text { PPV + ICG ILM } \\
\text { Peel + SF6 } \\
\text { Post operative } \\
\text { prone posi- } \\
\text { tion } 1 \text { week }\end{array}$ & $\begin{array}{l}\text { Macular hole } \\
\text { closed }\end{array}$ & $20 / 60$ \\
\hline Donnio 2008 & $\begin{array}{l}\text { Bartonella } \\
\text { Neuroreti- } \\
\text { nitis }\end{array}$ & 1 & 1 & $\begin{array}{l}11 \text { years } \\
M\end{array}$ & $20 / 200$ & Not reported & No & Not reported & Not reported \\
\hline Kumar 2010 & Coats' Disease & 1 & 1 & $\begin{array}{l}9 \text { years } \\
M\end{array}$ & $20 / 400$ & Not reported & No & Not reported & Not reported \\
\hline Wong 2012 & Coats' Disease & 1 & 1 & $\begin{array}{l}10 \text { years } \\
\mathrm{M}\end{array}$ & 20/150 & Not reported & $\begin{array}{l}\text { Yes } \\
\text { PPV + Autolo- } \\
\text { gous } \\
\text { plasmin } \\
\text { enzyme } \\
\text { injection } \\
\text { PPV + ICG ILM } \\
\text { peel + C3F8 } \\
\text { tamponade }\end{array}$ & $\begin{array}{l}\text { Macular hole } \\
\text { closed }\end{array}$ & $20 / 60$ \\
\hline Park 2012 & $\begin{array}{l}\text { Idiopathic } \\
\text { Cavitary Macu- } \\
\text { lopathy }\end{array}$ & 1 & 1 & $\begin{array}{l}8 \text { years } \\
F\end{array}$ & $20 / 40$ & Not reported & $\begin{array}{l}\text { Yes } \\
\text { PPV + ILM } \\
\text { peel + C3F8 } \\
\text { Post opera- } \\
\text { tive prone } \\
\text { position } \\
2 \text { weeks }\end{array}$ & $\begin{array}{l}\text { Macular hole } \\
\text { closed }\end{array}$ & $20 / 40$ \\
\hline
\end{tabular}


Table 1 (continued)

\begin{tabular}{|c|c|c|c|c|c|c|c|c|c|}
\hline $\begin{array}{l}\text { Author, case } \\
\text { year }\end{array}$ & $\begin{array}{l}\text { Associated } \\
\text { cause } \\
\text { of macular } \\
\text { hole }\end{array}$ & $\begin{array}{l}\text { No. } \\
\text { of patients }\end{array}$ & Pt no. & $\begin{array}{l}\text { Patient age } \\
\text { (months, } \\
\text { yrs), gender }\end{array}$ & $\begin{array}{l}\text { Presenting } \\
\text { BCVA }\end{array}$ & $\begin{array}{l}\text { Size of hole } \\
(\mu \mathrm{m})\end{array}$ & Surgery & Outcome & $\begin{array}{l}\text { Last exam } \\
\text { BCVA }\end{array}$ \\
\hline $\begin{array}{l}\text { Fernandez } \\
2013\end{array}$ & $\begin{array}{l}\text { Accidental } \\
\text { Nd:YAG laser }\end{array}$ & 1 & 1 & $\begin{array}{l}11 \text { years } \\
M\end{array}$ & $20 / 100$ & $1077 \mu \mathrm{m}$ & $\begin{array}{l}\text { Yes } \\
\text { PPV + ILM } \\
\text { Peel + C3F8 } \\
\text { Post operative } \\
\text { prone posi- } \\
\text { tion } 1 \text { week }\end{array}$ & $\begin{array}{l}\text { Macular hole } \\
\text { closed }\end{array}$ & $20 / 25$ \\
\hline Seth 2015 & $\begin{array}{l}\text { Bartonella } \\
\text { Neuroreti- } \\
\text { nitis }\end{array}$ & 1 & 1 & $\begin{array}{l}11 \text { years } \\
\mathrm{F}\end{array}$ & CF 1 foot & Not reported & No & Not reported & Not reported \\
\hline Bansal 2017 & $\begin{array}{l}\text { Choroidal } \\
\text { Coloboma }\end{array}$ & 1 & 1 & $\begin{array}{l}10 \text { years } \\
\mathrm{F}\end{array}$ & $20 / 60$ & Not reported & Not reported & Not reported & Not reported \\
\hline
\end{tabular}

BCVA best corrected visual acuity, PPV pars plana vitrectomy, FAX fluid air exchange, ILM internal limiting membrane, CF count fingers, NLP no light perception, ICG indocyanine green, C3F8 Perfluoropropane, SF6 sulfur hexafluoride

closure was attempted in 9 cases. Apart from the patients with ROP, the other 5 cases were treated with vitrectomy, ILM peel and gas tamponade. Anatomic closure of the hole was reported in all 5 cases $[4,7,13-15]$.

Macular surgery in the pediatric population has unique management and technical challenges. As previously mentioned, it may be difficult to accurately and reliably date how long the macular hole has been present. This poses a challenge when attempting to predict the presence of any contributory amblyopia to the presenting vision, and the potential visual benefit that can be expected from surgery. Induction of a PVD is difficult in children, and use of triamcinolone as in our case, may augment visualization of the posterior hyaloid. Fortunately for this patient, induction of the PVD was similar to that in an adult. Secondary complications including iatrogenic retinal tears and vitreous hemorrhage as a result of a young, adherent posterior hyaloid, in addition to late complications including vitrectomy induced cataract, should be considered carefully.

Finally, the ability to comply with post-operative care and practices including possible face down positioning are important in the pre-operative assessment of a child for macular surgery. Interestingly 3 cases specifically reported instructing their patient to position prone in the post-operative period $[4,13,15]$. These patients were of similar age to our patient, and also achieved macular hole closure.

\section{Conclusion}

This is the first reported case of an idiopathic FTMH in a child. Treatment with pars plana vitrectomy with peeling of the ILM resulted in significant anatomic and functional improvement.

\section{Abbreviations}

FTMH: full thickness macula hole; VA: visual acuity; OCT: optical coherence tomography; PVD: posterior vitreous detachment; ILM: internal limiting membrane; SF6: sulfur hexafluoride; ROP: retinopathy of prematurity; RPE: retinal pigment epithelium.

\section{Authors' contributions}

$J G$ reviewed the patient at first presentation. AH and GF performed surgery and post-operative care. LL and SL collated and prepared the patient data. $\mathrm{LL}$ was a major contributor in writing the manuscript. All authors read and approved the final manuscript.

\section{Author details}

1 Sydney Hospital and Sydney Eye Hospital, Macquarie Street, Sydney, NSW, Australia. ${ }^{2}$ Discipline of Ophthalmology, Sydney Eye Hospital Campus, University of Sydney, Macquarie Street, Sydney, NSW, Australia.

\section{Acknowledgements}

None.

\section{Competing interests}

The authors declare that they have no competing interests.

\section{Availability of data and materials}

The data in the current case report are available from the Sydney Eye Hospital and Save Sight Institute medical records. The data is available from the corresponding author on reasonable request.

\section{Consent for publication}

Consent for publication was obtained.

\section{Ethics approval and consent to participate}

Ethics approval for this research was obtained (South Eastern Sydney Local Health District Human Research Ethics Committee, HREC Ref Number: 17/232 LNR/17/POWH/529) SSA Ref 18/G/019). Consent for participation was obtained.

\section{Funding}

Drs Fernandez and Levasseur received funding from the Sydney Eye Hospital Foundation.

\section{Publisher's Note}

Springer Nature remains neutral with regard to jurisdictional claims in published maps and institutional affiliations. 
Received: 21 February 2018 Accepted: 3 July 2018

Published online: 11 July 2018

\section{References}

1. Alexandre de Amorim Garcia Filho C, Yehoshua Z, Gregori G, et al. Optical coherence tomography. In: Schachat A, Wilkinson C, Hinton D, et al., editors. Ryan's Retina, vol. 1. 5th ed. Beijing: Saunders; 2013. p. 89.

2. American Academy of Ophthalmology Retina/Vitreous Panel. Preferred practice pattern ${ }^{\circledR}$ guidelines. Idiopathic macular hole. San Francisco: American Academy of Ophthalmology; 2014. www.aao.org/ppp.

3. Huang J, Liu X, Wu Z, et al. Comparison of full-thickness traumatic macular holes and idiopathic macular holes by optical coherence tomography. Graefes Arch Clin Exp Ophthalmol. 2010;248:1071-5.

4. Park JC, Frimpong-Ansah KN. Idiopathic macula hole in a child. Eye. 2012;26:620-1.

5. Johnson RN, McDonald R, Lewis $\mathrm{H}$, et al. Traumatic macular hole: observations, pathogenesis, and results of vitrectomy surgery. Ophthalmology. 2001;108:853-7.

6. Ahmad OF, Hirose T. Retinal detachment with macular holes in infants with retinopathy of prematurity. Arch Ophthalmol. 2005;123:54-7.
7. Wong SC, Neuwelt MD, Tresse MT. Delayed closure of paediatric macular hole in Coats' disease. Acta Ophthalmol. 2012;90:e326-7.

8. Kumar V, Neha G, Basudeb G. Full-thickness macular hole and macular telangiectasia in a child with coats' disease. Ophthalmic Surg Lasers Imaging. 2010;30:41.

9. Albini TA, Lakhanpal RR, Foroozan R, et al. Macular hole in cat scratch disease. Am J Ophthalmol. 2005;140(1):149-51.

10. Donnio A, Jean-Charles A, Merle H. Macular hole following Bartonella henselae neuroretinitis. Eur J Ophthalmol. 2008;18(3):456-8.

11. Seth A, Raina UK, Thirumalai S, et al. Full-thickness macular hole in Bartonella henselae neuroretinitis in an 11-year-old girl. Oman J Ophthalmol. 2015;8(1):44-6. https://doi.org/10.4103/0974-620x.149866.

12. Bansal P, Chawla R, Sharma A. Pediatric choroidal coloboma with macular hole at the edge of the coloboma. Ophthalmology. 2017;124(5):666.

13. Nakano T, Uemura A, Kanda S, et al. A nontraumatic macula hole in a 10-year-old girl. Jpn J Ophthalmol. 2005;49:520-2.

14. Yokoyama T, Watanabe Y, Murakami A. Macular hole secondary to epiretinal membrane in a juvenile patient. Am J Ophthalmol. 2005:139:357-9.

15. Fernandez MP, Modi YS, John VJ, et al. Accidental Nd:YAG laser-induced macular hole in a paediatric patient. Ophthalmic Surg Lasers Imaging Retina. 2013;44:e7-10.
Ready to submit your research? Choose BMC and benefit from:

- fast, convenient online submission

- thorough peer review by experienced researchers in your field

- rapid publication on acceptance

- support for research data, including large and complex data types

- gold Open Access which fosters wider collaboration and increased citations

- maximum visibility for your research: over $100 \mathrm{M}$ website views per year

At BMC, research is always in progress.

Learn more biomedcentral.com/submissions 